\title{
Effect of slag chemistry on the hydration of alkali-activated blast-furnace slag
}

\author{
Ricarda Tänzer • Anja Buchwald • \\ Dietmar Stephan
}

Received: 22 April 2014 / Accepted: 23 October 2014/Published online: 20 November 2014

(C) The Author(s) 2014. This article is published with open access at Springerlink.com

\begin{abstract}
This paper presents results of detailed investigations about the alkaline activation of ground granulated blast furnace slags whose chemical composition were modified. Sodium hydroxide and potassium silicates were used as alkaline activators. The influence of the $\mathrm{CaO} / \mathrm{SiO}_{2}$ ratio, the $\mathrm{Al}_{2} \mathrm{O}_{3}$ and $\mathrm{TiO}_{2}$ content of the slag composition on the hydration reaction was analyzed utilizing isothermal heat flow calorimetry, compressive strength development of binder samples, ${ }^{29} \mathrm{Si}$ MAS NMR spectroscopy and molybdate method. It could be shown that the $\mathrm{TiO}_{2}$ content of the slag has only minor influence on the hydraulic reactivity and compressive strength of the alkaline activated binders. The variation of the $\mathrm{Al}_{2} \mathrm{O}_{3}$ content of the slag leads to different results. A rise in $\mathrm{Al}_{2} \mathrm{O}_{3}$ content enhanced the strength if activating with $\mathrm{NaOH}$ but resulted in a lower strength if activating with potassium silicate. The results of the ${ }^{29} \mathrm{Si}$ MAS NMR spectroscopy verify the decrease in the reaction degree with increase of $\mathrm{Al}_{2} \mathrm{O}_{3}$ content. This is associated with the rise of the chain length of the $\mathrm{C}-(\mathrm{A})-\mathrm{S}-\mathrm{H}$ phases by incorporation of $\mathrm{Al}-\mathrm{O}$ tetrahedrons resulting in a lower
\end{abstract}

R. Tänzer $(\bowtie) \cdot$ D. Stephan

Building Materials and Construction Chemistry, Technische Universität Berlin, Gustav-Meyer-Allee 25, 13355 Berlin, Germany

e-mail: ricarda.taenzer@tu-berlin.de

A. Buchwald

ASCEM B.V, Schaarweg 4, 6991 GV Rheden, The

Netherlands
Si/Al-ratio. A decrease in the C/S-ratio yielded to a lower heat evolution, whereas the reaction was delayed if activated with potassium silicate with higher silicate content. The increase of the C/S-ratio caused in less condensed slag glass and therefore an enhancement of the reaction degree with a simultaneous decrease of silicate chain length, as seen by ${ }^{29} \mathrm{Si}$ NMR. These outcomes fit well with the results measured by the molybdate method.

Keywords Ground granulated blast-furnace slag . Alkali silicates · Alkali activation $\cdot{ }^{29} \mathrm{Si} \mathrm{NMR}$. Molybdate method

\section{Introduction and background}

Granulated blast furnace slag, a by-product of the raw iron production, is almost exclusively used as a main ingredient of standard cements in Germany so far. A key aspect of slag research is therefore the identification of assessment criteria for the reactivity of ground granulated blast furnace slag (GGBFS). The positive effect of some oxides $\left(\mathrm{CaO}, \mathrm{MgO}, \mathrm{K}_{2} \mathrm{O}, \mathrm{Na}_{2} \mathrm{O}\right)$ or the adverse effect of a high content of $\mathrm{SiO}_{2}, \mathrm{TiO}_{2}$ or $\mathrm{MnO}$ in the GGBFS on its reactivity are known [1]. However these indicators only allow a very rough estimate of the reactivity of blast furnace slag as a cement component $[2,3]$. Additionally various empirical indicators (Table 1, [4-9]) are used for the correlation between 
chemical composition and technical properties $[4,10]$. These indicators does not predict reliable the properties of the resulting cements. Key parameters of the production process itself such as temperature in the furnace, viscosity of the liquid slag and conditions for granulation may also play an important role $[11,12]$. For that reason the compressive strength of mortars made from the cements containing these GGBFS is used as a safe evaluation criterion. The influence of different major and minor components of the GGBFS on the strength development was investigated frequently. Especially the influence of the $\mathrm{Al}_{2} \mathrm{O}_{3}$ content on the strength development because of an increased basicity was documented rather early [2] resulting in a positive influence on the early age strength, which may have a negative effect on the strength at later ages. The correlation between the chemical-mineralogical composition of the slag and the properties of the resulting binder have to be asked again with the upcoming interest in utilizing GGBFS for the production of alkali activated materials. If GGBFS is activated with alkali hydroxides, carbonates or silicates the correlations known for the activation with Portland cement might be not further valid or even more complex. Sakulich et al. [13] investigated the influence of adding $\mathrm{Al}_{2} \mathrm{O}_{3}$ to slags activated with $\mathrm{NaOH} /$ water glass solutions. The increase in compressive strength after 7 and 28 days was observed if adding low amounts of $\mathrm{Al}_{2} \mathrm{O}_{3}$, whereas a further addition of $\mathrm{Al}_{2} \mathrm{O}_{3}$ caused a delay of the hydration and did not enhance the mechanical properties. Ben Haha et al. [14] investigated slags with different $\mathrm{Al}_{2} \mathrm{O}_{3}$ contents activated with $\mathrm{NaOH}$ and sodium silicate solutions. It was found using isothermal calorimetry that an increased $\mathrm{Al}_{2} \mathrm{O}_{3}$ content of the slag slows down the rate of hydration. A high $\mathrm{Al}_{2} \mathrm{O}_{3}$ content resulted in a clear delay of the main reaction peak if activating with silicate solution, but accelerated the main reaction peak if activating with $\mathrm{NaOH}$. In fact a lower strength at early ages was reached with higher $\mathrm{Al}_{2} \mathrm{O}_{3}$ content compared to the original slag but no significant differences at later times.

There are only few studies about the influence of $\mathrm{MgO}$ in slags. Ben Haha et al. [15] could show that an increasing $\mathrm{MgO}$ content of the slag from 8 to $13 \mathrm{wt} \%$ accelerated the reaction and resulted in higher compressive strengths. How much the reaction will be accelerated depended on the type of activator. A faster reaction and a higher strength was achieved using $\mathrm{NaOH}$ as activator instead of sodium silicate. The
Table 1 Selection of different empirical indicators for correlation of chemical composition and technical characteristics of GGBFS [4]

\begin{tabular}{lc}
\hline Empirical indicators & Suggestion/source (year) \\
\hline$p_{1}=\frac{\mathrm{CaO}}{\mathrm{SiO}_{2}}>1$ & "Basic" basicity (1885) \\
$p_{2}=\frac{\mathrm{CaO}+\mathrm{MgO}}{\mathrm{SiO}_{2}}>1$ & [5] \\
$\mathrm{CaO}+\mathrm{MgO}+\mathrm{SiO}_{2}>2 / 3$ & DIN EN 15167-1 (2006) \\
$p_{3}=\frac{\mathrm{CaO}+\mathrm{MgO}^{-}}{\mathrm{SiO}_{2}+\mathrm{Al}_{2} \mathrm{O}_{3}} \geq 1$ & [7] \\
& German standard for "slag \\
& Portland cement" (1909) \\
$F=\frac{\mathrm{CaO}+1 / 2 \mathrm{~S}^{2-}+1 / 2 \mathrm{MgO}+\mathrm{Al}_{2} \mathrm{O}_{3}}{\mathrm{SiO}_{2}+\mathrm{MnO}}>1.5$ & F-value by Keil [9] \\
\hline
\end{tabular}

differences between slags containing little or much $\mathrm{MgO}$ were more distinctive if activating with sodium silicate, although comparable degrees of slag reaction were detected. Bernal et al. [16] showed that a low content of $\mathrm{MgO}$ content leads to a faster reaction (in contrast to the results published by Ben Haha), whereas the overall extent of reaction was reduced. Both Bernal and Ben Haha $[15,16]$ verified that a lower $\mathrm{MgO}$ content favors the incorporation of $\mathrm{Al}-\mathrm{O}$ tetrahedrons into the $\mathrm{C}-\mathrm{S}-\mathrm{H}$ chains.

Studies on cements containing blast furnace slag have demonstrated that the $\mathrm{TiO}_{2}$ content of GGBFS has a substantial influence on the reaction behavior and that an increased $\mathrm{TiO}_{2}$ content $>1 \mathrm{wt} \%$ has a negative effect on the strength development [4]. According to Wolter et al. and Wang et al. $[17,18] \mathrm{TiO}_{2}$ in the melt is present as $\mathrm{Ti}^{4+}$ and $\mathrm{Ti}^{3+}$ and can replace $\mathrm{Si}^{4+}$ acting as a network former in the glass network. This results in a densification of the glass structure and the increase of particle density as well as corrosion resistance. Subsequent the higher corrosion resistance leads to a worse dissolution of the glass network.

The production conditions of the slag have a significant influence and were different in diverse investigations which impede a clear correlation between the chemical-mineralogical composition of the GGBFS and its technical behavior towards individual activators could be derived [19]. The way out could be the use of synthetic slag. It is possible to pursue the influence of different parameters (basicity, $\mathrm{Al}_{2} \mathrm{O}_{3}$ content etc.) of the blast furnace slag without having a superposition of different chemical and other influences, as it is inevitably when using different industrially produced granulated slags. This way is 
Table 2 Chemical composition of the GGBFSs utilized

\begin{tabular}{llllllll}
\hline GGBFS & $\begin{array}{c}\mathrm{CaO} \\
\text { wt\% }\end{array}$ & $\mathrm{SiO}_{2}$ & $\mathrm{Al}_{2} \mathrm{O}_{3}$ & $\mathrm{MgO}$ & $\mathrm{TiO}_{2}$ & $\begin{array}{c}\mathrm{S}_{\text {total }} \\
\text { C/S } \\
-\end{array}$ \\
\hline S1 & 42.5 & 34.8 & $\mathbf{1 1 . 4}$ & 8.3 & $\mathbf{0 . 5}$ & 0.8 & $\mathbf{1 . 2 2}$ \\
S2 & 41.6 & 34.4 & 12.0 & 8.2 & $\mathbf{1 . 9}$ & 0.6 & 1.21 \\
S3 & 37.7 & 31.0 & $\mathbf{2 1 . 6}$ & 7.3 & 0.4 & 0.8 & 1.22 \\
S4 & 45.4 & 31.9 & 13.3 & 7.8 & 0.4 & 0.4 & $\mathbf{1 . 4 2}$ \\
S5 & 35.2 & 41.1 & 13.7 & 7.8 & 0.6 & 0.3 & $\mathbf{0 . 8 6}$ \\
\hline
\end{tabular}

Bold numbers are the criteria which are compared

chosen for the investigations described. The basis was a conventional GGBFS which was modified by adding several oxides, re-molten and granulated again and milled under identical laboratory conditions. The focus was set on the influence of the $\mathrm{CaO} / \mathrm{SiO}_{2}$ ratio, the $\mathrm{Al}_{2} \mathrm{O}_{3}$ and $\mathrm{TiO}_{2}$ content.

\section{Materials and methods}

\subsection{Ground granulated blast furnace slag (GGBFS) and alkaline activators}

The original base material of the studies was an industrial GGBFS. This slag was modified with pure oxides to reach the desired composition and re-molten in a graphite crucible under nitrogen atmosphere at temperatures between 1,550 and $1,650{ }^{\circ} \mathrm{C}$. Subsequently it was granulated in a laboratory wet granulation system. This procedure was chosen to guarantee absolute identical production conditions for all slags investigated to pursue the influence of certain chemical constituents on the reactivity of the GGBFS. In this paper, however, the influence of the basicity (C/Sratio), ${ }^{1}$ the $\mathrm{TiO}_{2}$ content and the $\mathrm{Al}_{2} \mathrm{O}_{3}$ content of the slag will be discussed. Table 2 summarizes the chemical characteristics of the GGBFSs used. The glass content was determined by light microscopy. Therefore the crystalline and glassy components of 1,000 slag grains (fraction $40-63 \mu \mathrm{m}$ ) were counted [20]. The glass content was determined between 98 and $100 \mathrm{wt} \%$. The slags were ground in a ball mill for the further use as binder material. The particle size distributions of the grinded GGBFSs were comparable to each other with $d_{50}$ values of 11-12 $\mu \mathrm{m}$ and Blaine

\footnotetext{
$\overline{1}$ Cement nomenclature: $\mathrm{C}=\mathrm{CaO}, \mathrm{S}=\mathrm{SiO}_{2}$.
}

fineness between 4,100 and $4,300 \mathrm{~cm}^{2} / \mathrm{g}$. Only GGBFS S2 was slightly finer with a $d_{50}$ value of $9 \mu \mathrm{m}$ and a Blaine fineness of approximately $4,800 \mathrm{~cm}^{2} / \mathrm{g}$.

Sodium hydroxide $(\mathrm{NaOH})$ and two potassium silicate solutions with molar water glass modules $\left(\mathrm{SiO}_{2} / \mathrm{M}_{2} \mathrm{O}\right)$ of 1 and 2 were used as alkaline activators (Table 3). Furthermore a water/slag-ratio of 0.35 was defined for all alkali-activated binders to allow a comparability between them, because of the different solid contents of the alkaline solutions used. Pure binder paste samples without any aggregates were prepared and used in all investigations.

\subsection{Experimental investigation}

At first the binder reaction of the alkali-activated GGBFSs were followed by isothermal heat flow calorimetry (TAMair, Thermometric) at $20{ }^{\circ} \mathrm{C}$. Sample specimen measuring $2 \times 2 \times 2 \mathrm{~cm}^{3}$ were prepared for mechanical testing of the hardened binders. The samples were kept in moulds at $20^{\circ} \mathrm{C}$ for one day, then demoulded and stored afterwards at $20^{\circ} \mathrm{C}$ and $100 \%$ RH until the date of testing the compressive strength. In order to characterize the reaction products the hydration was stopped by means of vacuum drying at day 1, 7, 28 and 180 after preparation. The dried samples were ground to a fineness $<63 \mu \mathrm{m}$.

${ }^{29} \mathrm{Si}$ nuclear magnetic resonance spectroscopy (MAS NMR) is a method for quantification of the silicate phases which deemed to be the most suitable method in these amorphous systems. Solid state NMR experiments were performed with a Bruker Avance 300 spectrometer (magnetic field strength $7.0455 \mathrm{~T}$, resonance frequency of ${ }^{29} \mathrm{Si}$ is $59.63 \mathrm{~Hz}$ ). To measure the ${ }^{29} \mathrm{Si}$ MAS NMR spectra, the samples were packed in $7 \mathrm{~mm}$ zirconia rotors and spun at $5 \mathrm{kHz}$ at an angle of $54^{\circ} 44^{\prime}$. The chemical shifts were recorded relative to external tetramethylsilane (TMS). The single pulse technique was applied with a pulse width of $4 \mu \mathrm{s}$. According to the high paramagnetic portion of the samples, a short repetition time of $5 \mathrm{~s}$ was chosen and a typical number of scans were 40,000. Thirty Hertz line broadening was applied to all spectra prior to deconvolution. The quantitative analysis that means the deconvolution of the signal patterns of the spectra was done with the software PeakFit of Scientific Solutions.

A second method for characterization of silicate species is the so called "molybdate method". Silicate 
Table 3 Chemical composition of the used activators and binders

\begin{tabular}{|c|c|c|c|c|c|c|c|}
\hline \multicolumn{6}{|l|}{ Solution } & \multirow{2}{*}{\multicolumn{2}{|c|}{$\frac{\text { Binder }}{\text { Mass-ratio }}$}} \\
\hline & $\mathrm{n}_{\text {alkali }} / \mathrm{m}_{\text {solution }}$ & Mass- & ontent & & & & \\
\hline & $\mathrm{mol} / \mathrm{kg}$ & $\begin{array}{l}\mathrm{Na}_{2} \mathrm{O} \\
\mathrm{wt} \%\end{array}$ & $\mathrm{~K}_{2} \mathrm{O}$ & $\mathrm{SiO}_{2}$ & Total solid & $\begin{array}{l}\mathrm{m}_{\mathrm{Na} 2 \mathrm{O}} / \mathrm{m}_{\mathrm{GGBFS}} \\
\%\end{array}$ & $\mathrm{~m}_{\mathrm{K} 2 \mathrm{O}} / \mathrm{m}_{\mathrm{GGBFS}}$ \\
\hline $\mathrm{NaOH}$ & 2.0 & 6.2 & - & - & 6.2 & 2.4 & - \\
\hline K-WG-1 & 2.0 & - & 9.4 & 6.0 & 15.4 & - & 3.6 \\
\hline K-WG-2 & 2.0 & - & 9.4 & 12.0 & 21.4 & - & 3.6 \\
\hline
\end{tabular}

species react in sulphuric acid ( $\mathrm{pH}$ value of $1-2)$ with ammonium heptamolybdate solution $\left[(\mathrm{NH})_{4} \mathrm{Mo}_{7} \mathrm{O}_{24}\right.$ $\left.4 \mathrm{H}_{2} \mathrm{O}\right]$ to yellow-colored $\beta$-silico-molybdic acid complex $\left(\mathrm{H}_{4} \mathrm{SiMo}_{12} \mathrm{O}_{40}\right)$ [21-23]. The reaction progress can be monitored by UV-Vis spectrometry at a wavelength of $400 \mathrm{~nm}$. The temperature was always set to $25{ }^{\circ} \mathrm{C}$. The hydrolysis obeys the rate law of first order, and therefore it is possible to conclude from the rate constant to the degree of condensation of the silicate contained in the sample [23]. However the evaluation of the results is not clearly in the case of alumosilicates, because of the dissolution of the sample in acid in what the Al-O-Si bonds will be broken. Therefore only the degree of condensation of the (remaining) silicates can be measured [24]. The longer the reaction takes, the higher was the condensation of silicate in the binder, which is indicated by the rate constant $\mathrm{k}$. It is possible to deduce the amount of $\mathrm{SiO}_{2}$ units in the reaction products from the determined rate constant by comparing with values of known silicate species [23, 25-28]. Furthermore, the degree of condensation of the silicate contained in the sample can be calculated using the maximum extinction. This value is based on the $\mathrm{SiO}_{2}$ content of the binder, which is calculated from the composition of the raw materials (slag + activator) and the loss on ignition of the binder. Inasmuch it could have been come to minor changes due to carbonation during preparation of the binder (e.g. reaction, grinding), solely the tendency of the "molybdate active $\mathrm{SiO}_{2}$ " can be considered.

\section{Results and discussions}

\subsection{Isothermal calorimetry}

Figure 1 shows the isothermal heat flow calorimetry of different GGBFSs activated with sodium hydroxide and potassium silicate solutions.
Wolter et al. and Wang et al. [17, 18] reported that $\mathrm{TiO}_{2}$ can replace $\mathrm{Si}^{4+}$ in the glass network resulting in a densification of the glass structure and a higher corrosion resistance. If this higher corrosion resistance and potassium silicate this should be measurable with heat flow calorimetry. Figure 1a depicts that S2 (high $\mathrm{TiO}_{2}$ content) shows a lower heat flow which is $1.5 \mathrm{~h}$ delayed compared to $\mathrm{S} 1$ if activated with K-WG-1. However the cumulated heat after $72 \mathrm{~h}$ was nearly the same (Table 4). In case of using $\mathrm{NaOH}$ as activator both heat flow curves look similar but the cumulated heat of the reaction of S2 is $12 \%$ higher than that of $\mathrm{S} 1$. Presumably this might be related to the higher fineness of $\mathrm{S} 2 \quad\left(4,800 \mathrm{~cm}^{2} / \mathrm{g}\right.$ instead of approx. $4,200 \mathrm{~cm}^{2} / \mathrm{g}$ ).

The modification of the $\mathrm{Al}_{2} \mathrm{O}_{3}$ content led not to a systematic correlation to the hydraulic reactivity of the slag. The highest heat flow maximum occurred of activating GGBFS $\mathrm{S} 3$ (high $\mathrm{Al}_{2} \mathrm{O}_{3}$ content of 21.6 wt\%) with $\mathrm{NaOH}$ (Fig. 1b) which is in agreement with the results of Ben Haha et al. [14]. The cumulated heat of S3 was higher compared to the binder with S1 (low $\mathrm{Al}_{2} \mathrm{O}_{3}$ content). The activation of both GGBFSs with K-WG-1 show contrary results. The intensity of the heat flow peak of S3 was lower but at an earlier time than of that of S1. The observed results of the main hydration peak are similar to that of the initial peak found by Ben Haha. He measured an initial peak in the first minutes and a second main peak which showed a long dormant period of more than $60 \mathrm{~h}$. Such a second, delayed peak could not be observed. It has to be mentioned that the samples were mixed outside the calorimeter. Therefore it is not possible to follow the first minutes of the reaction.

The influence of the C/S-ratio was studied on the slags S1, S4 and S5. The C/S-ratio ranges from 0.86 for $\mathrm{S} 5$ over 1.22 for $\mathrm{S} 1$ to 1.42 for $\mathrm{S} 4$. If the basicity of the slag (C/S-ratio) rises, the content of $\mathrm{CaO}$ increases is influencing the activation with sodium hydroxide 

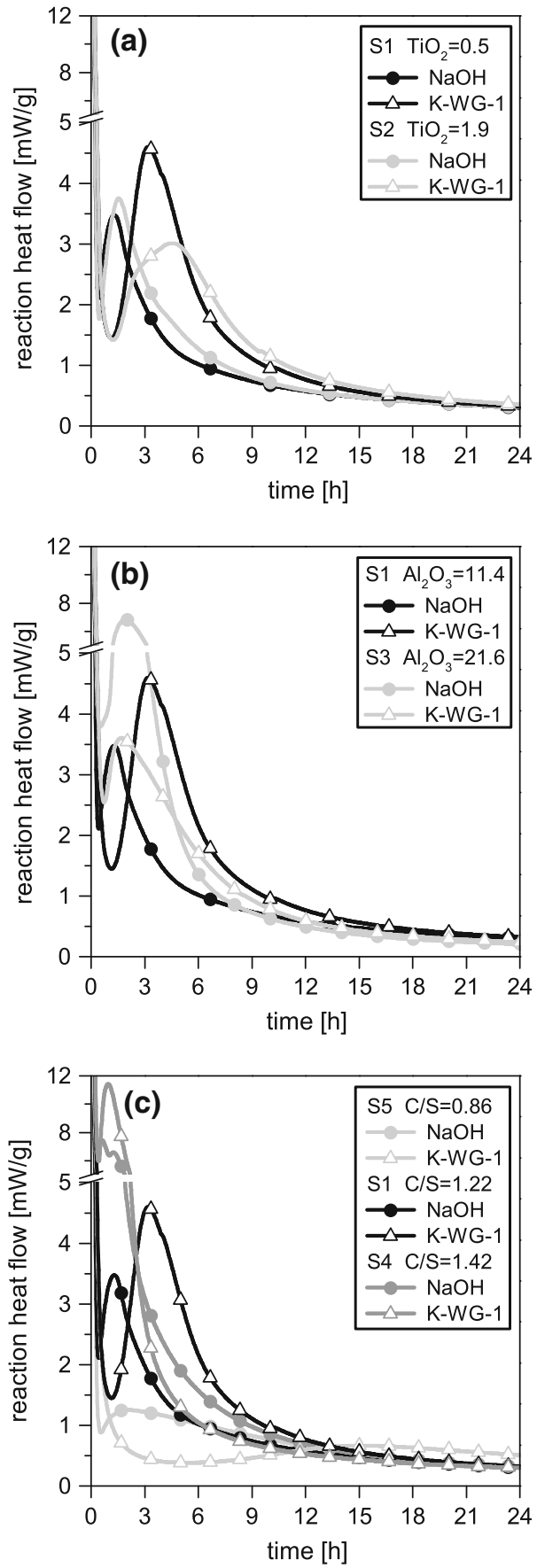

Fig. 1 Isothermal heat flow calorimetry of different GGBFSs with sodium hydroxide and potassium silicate as activator, comparison of different a $\mathrm{TiO}_{2}$ contents in wt $\%, \mathbf{b} \mathrm{Al}_{2} \mathrm{O}_{3}$ contents in $\mathrm{wt} \% \mathrm{c}$ C/S-ratios

with a simultaneous decrease of $\mathrm{SiO}_{2}$ which leads to an expansion of the glass network and facilitate splitting of existing $\mathrm{Si}-\mathrm{O}$-bonds. This usually results in a better dissolution/reactivity of the slag and a faster strength development. The question arises if this increasing reactivity has an impact if different alkaline activators are used. Figure 1c shows the heat flow of the binders activated with $\mathrm{NaOH}$ and K-WG-1. For $\mathrm{NaOH}$, the enhanced reactivity of S4 compared to S1 and S5 is characterized by an increased intensity in the heat flow as well as a significantly higher heat release (Table 4). After $72 \mathrm{~h}$ the heat of hydration of the samples S1 and S5 is $28 \%$ respectively $37 \%$ lower than that of S4. If the same samples were activated with silicate (K-WG-1) a distinct time shift is seen in addition to the steplike heat flow maxima. The binder with $\mathrm{S} 4$ again showed the highest heat release. The heat release of the binder with S5 is with $32 \%$ less compared to the binder with S4 and thus almost the same as for the activation with $\mathrm{NaOH}$. But the difference of the heat release of the binder with $\mathrm{S} 1$ compared to S4 is only $8 \%$ less (within $72 \mathrm{~h}$ ). The reason for this is supposedly that the activator $\mathrm{NaOH}$ is stronger in the beginning. More hydroxide ions could dissolve the slag glass and the mean reaction as characterized by the heat flow was measured during the first $6 \mathrm{~h}$. The hydroxide concentration of the K-WG-1 silicate solution was lower and dissolved the slag glass slower but the incorporation of additional $\mathrm{SiO}_{2}$ in the reaction products resulted in a larger amount of heat released within the first $72 \mathrm{~h}$.

\subsection{Compressive strength}

Figure 2 shows the compressive strength development of different GGBFSs activated with sodium hydroxide and potassium silicate as activators.

The influence of the $\mathrm{TiO}_{2}$ contents on the compressive strength (Fig. 2a) is much more significant than on the heat flow calorimetry. If activating with $\mathrm{NaOH}$ the 28 days strength of the binder with S2 (high $\mathrm{TiO}_{2}$ content of $1.9 \mathrm{wt} \%$ ) is $74 \%$ higher than that of the binder with $\mathrm{S} 1$ (low $\mathrm{TiO}_{2}$ content of $0.5 \mathrm{wt} \%$ ) while it is only $8 \%$ higher if activating with K-WG-1. But with K-WG-1 the deviation in compressive strength is in some cases significantly higher than that for the binder with $\mathrm{NaOH}$. Even if it can be supposed that a part of the strength results from the slightly higher fineness of the GGBFS S2, it can be assumed that no major losses in the hydraulic reactivity of S2 compared with $\mathrm{S} 1$ can be observed in alkali-activated binders. The strength reduction as known from 
Table 4 Cumulative heat released after $3,6,12,24$ and $72 \mathrm{~h}(\mathrm{~J} / \mathrm{g})$

\begin{tabular}{|c|c|c|c|c|c|c|c|c|c|}
\hline \multirow[t]{2}{*}{ GGBFS } & \multirow{2}{*}{$\begin{array}{l}\mathrm{TiO}_{2} \\
\text { wt } \%\end{array}$} & \multirow[t]{2}{*}{$\mathrm{Al}_{2} \mathrm{O}_{3}$} & \multirow{2}{*}{$\begin{array}{l}\mathrm{C} / \mathrm{S} \\
-\end{array}$} & \multirow[t]{2}{*}{ Activator } & \multicolumn{5}{|c|}{ Time (h) } \\
\hline & & & & & 3 & 6 & 12 & 24 & 72 \\
\hline S1 & 0.5 & 11.4 & 1.22 & $\mathrm{NaOH}$ & 43.4 & 58.2 & 74.6 & 92.4 & 121.1 \\
\hline $\mathrm{S} 2$ & 1.9 & 12.0 & 1.21 & & 47.5 & 66.5 & 84.7 & 102.6 & 135.4 \\
\hline S3 & 0.4 & 21.6 & 1.22 & & 71.8 & 102.1 & 119.1 & 132.4 & 153.1 \\
\hline S4 & 0.4 & 13.3 & 1.42 & & 70.0 & 93.7 & 115.9 & 135.5 & 167.7 \\
\hline S5 & 0.6 & 13.7 & 0.86 & & 26.4 & 38.6 & 56.6 & 75.5 & 105.2 \\
\hline S1 & 0.5 & 11.4 & 1.22 & K-WG-1 & 46.7 & 85.0 & 111.4 & 132.0 & 162.2 \\
\hline $\mathrm{S} 2$ & 1.9 & 12.0 & 1.21 & & 40.3 & 71.3 & 102.9 & 126.0 & 160.0 \\
\hline S3 & 0.4 & 21.6 & 1.22 & & 52.8 & 78.6 & 100.2 & 115.7 & 139.2 \\
\hline S4 & 0.4 & 13.3 & 1.42 & & 94.5 & 111.9 & 127.4 & 144.0 & 176.7 \\
\hline S5 & 0.6 & 13.7 & 0.86 & & 26.7 & 31.0 & 41.2 & 67.6 & 119.4 \\
\hline
\end{tabular}

cements containing GGBFS with higher $\mathrm{TiO}_{2}$ contents and Portland cement clinker $[4,18]$ might be related to the other type of activation by $\mathrm{Ca}(\mathrm{OH})_{2}$, which is formed during the hydration of $\mathrm{C}_{3} \mathrm{~S}$ and $\mathrm{C}_{2} \mathrm{~S}$. There is still no explanation for the different mechanisms. But therefore the alkaline activation is of special interest for GGBFSs with high $\mathrm{TiO}_{2}$, as these cannot be sufficiently activated with Portland cement clinker.

The compressive strength of the binder with $\mathrm{S} 3$ (high $\mathrm{Al}_{2} \mathrm{O}_{3}$ content of $21.6 \mathrm{wt} \%$ ) activated with $\mathrm{NaOH}$ was significantly increased compared to those of S1 (Fig. 2b). After 1 day the compressive strength of the binder with S3 is 3 times higher and after 28 days and 180 days they are still almost twice as high as the strength values of the binder with $\mathrm{S} 1$. This confirms the experiences with blast furnace slag cements [29]. A completely different performance emerged if activating S1 and S3 with potassium silicate (K-WG-1). In this case the binder with $\mathrm{S} 1$ obtained higher strength over the entire duration of the measurement than that of the binder with S3. In addition the compressive strength of the binder with $\mathrm{S} 3$ activated with $\mathrm{K}-\mathrm{WG}-2$ is pictured. The doubling of the $\mathrm{SiO}_{2}$ content in the activator resulted in a significant rise in the compressive strength development especially after 28 and 180 days.

The early strengths after 1 day (Fig. 2c) were influenced by the C/S-ratio. The binder with S4 $(\mathrm{C} / \mathrm{S}=1.42)$ activated with $\mathrm{NaOH}$ reached the highest strength and the binder with $\mathrm{S} 5(\mathrm{C} / \mathrm{S}=0.86)$ activated with K-WG-1 reached the lowest strength after 1 day reaction. Interestingly, this negative effect of low basicity is compensated over time regarding the binder with K-WG-1. After 180 days the strength of the binder with S5 $(\mathrm{C} / \mathrm{S}=0.86)$ exceeded even that of the other binder with higher $\mathrm{C} / \mathrm{S}$ (S1 and S4). The reasoning is that the initial phase of the reaction is influenced by dissolving the glass, in which a high $\mathrm{pH}$ value of the activator has a positive effect. The subsequent course of the reaction goes together with a densification of the structure, which is achieved by precipitated and incorporated $\mathrm{SiO}_{2}$.

\subsection{Nuclear magnetic resonance spectroscopy}

The ${ }^{29} \mathrm{Si}$ NMR spectrum in Fig. 3 shows the modification of the glass network of GGBFS. Table 5 lists the values of the ${ }^{29} \mathrm{Si}$ chemical shift of the different GGBFS glass peaks.

According to Wolter et al. [17] even low $\mathrm{TiO}_{2}$ contents lead to changes in the glass structure. In the blast furnace slag glass $\mathrm{Ti}$ is simultaneously present in the oxidations states $\mathrm{Ti}^{4+}$ and $\mathrm{Ti}^{3+}$. According to the network hypothesis of Zachariasen $[30,31] \mathrm{Ti}^{4+}$ can replace $\mathrm{Si}^{4+}$ in the network as a network former, while $\mathrm{Ti}^{3+}$ preferably represents the $\mathrm{Ca}^{2+}$ instead. But in octahedral coordination it tightens the network in contrast to $\mathrm{Ca}^{2+}$ [17]. Various studies on titanosilicates showed that the $\mathrm{Ti}$ is present in these compounds in octahedral coordination $\left(\mathrm{TiO}_{6}\right)$. These $\mathrm{TiO}_{6}$ octahedra are linked to corner-sharing $\mathrm{SiO}_{4}$ tetrahedra through bridging oxygen atoms. Similar to aluminosilicates a systematic downfield shift in the Si-NMR spectra can be seen with increasing titanium nextnearest neighbors. Labouriau et al. have measured the following shifts for different $\mathrm{SiO}_{4}$ environments: 0Si,4Ti $=-78.5 \mathrm{ppm} ; \quad 1 \quad \mathrm{Si}, 3 \mathrm{Ti}=-82.0 \mathrm{ppm}$; $2 \mathrm{Si}, 2 \mathrm{Ti}=-90.6 \mathrm{ppm}$ and $3 \mathrm{Si}, 1 \mathrm{Ti}=-94.2 \mathrm{ppm}$ 

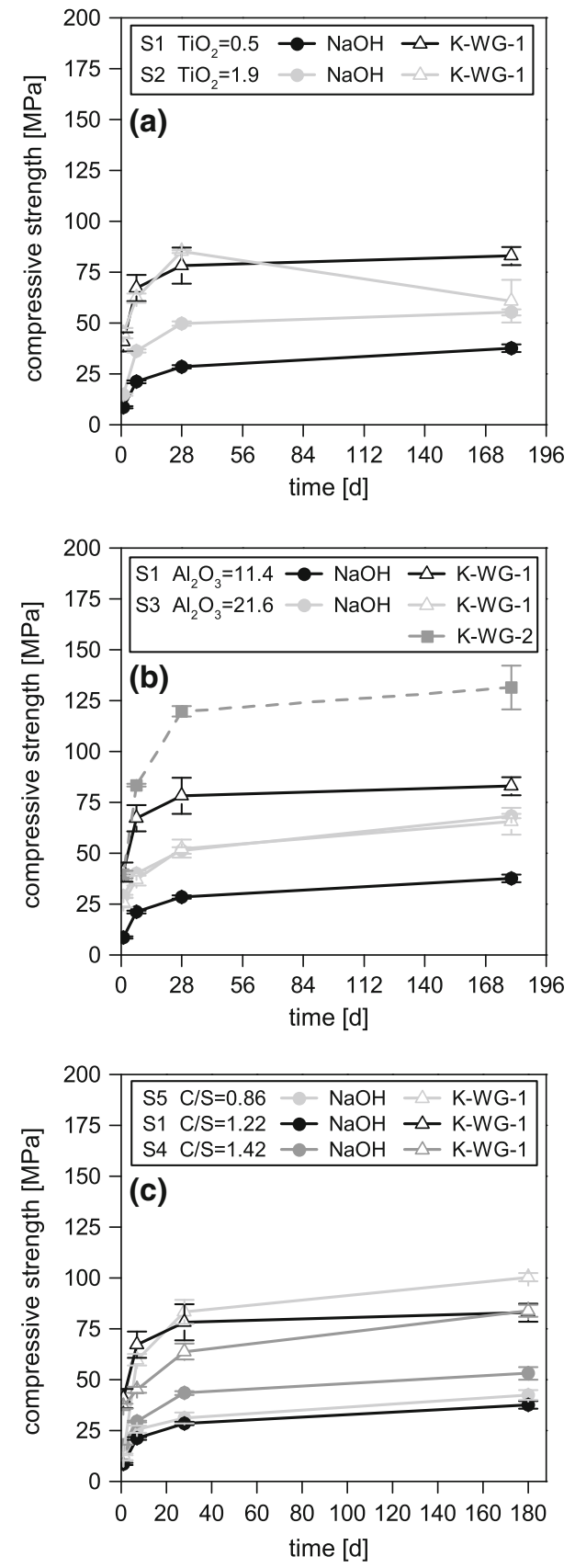

Fig. 2 Compressive strength development of different GGBFSs with sodium hydroxide and potassium silicate as activator, comparison of different a $\mathrm{TiO}_{2}$ contents in $\mathrm{wt} \%$, b $\mathrm{Al}_{2} \mathrm{O}_{3}$ contents in wt $\%$ c $\mathrm{C} / \mathrm{S}$-ratios

[32]. Balmer et al. reported that the effect on the chemical shift depends on the charge of the bond between $\mathrm{Si}$ and $\mathrm{Ti}$. A Si bond to tetrahedral Ti has a formal charge of 0 , and therefore no effect is expected [33]. The peak position of S2 with the significantly

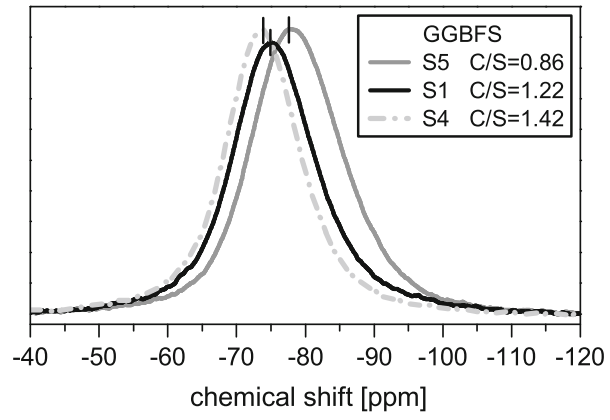

Fig. $3{ }^{29} \mathrm{Si}$ NMR-chemical shifts of GGBFS with different C/S-ratios

Table $5{ }^{29}$ Si MAS NMR spectroscopy of origin GGBFS glass and alkaline activated binders-peak positions and curve parameter used for deconvolution

\begin{tabular}{llll}
\hline $\begin{array}{l}\text { GGBFS/ } \\
\text { reaction } \\
\text { product }\end{array}$ & $\begin{array}{l}\text { Chemical } \\
\text { shift } \\
(\mathrm{ppm})\end{array}$ & $\begin{array}{l}\text { Half } \\
\text { width } \\
(\mathrm{ppm})\end{array}$ & $\begin{array}{l}\text { Gauss/ } \\
\text { Lorentz } \\
\text { ratio }\end{array}$ \\
\hline $\mathrm{S} 1$ & -75.4 & 13.9 & 0.40 \\
$\mathrm{~S} 2$ & -75.2 & 14.0 & 0.46 \\
$\mathrm{~S} 3$ & -76.3 & 14.2 & 0.44 \\
$\mathrm{~S} 4$ & -73.8 & 12.7 & 0.43 \\
$\mathrm{~S} 5$ & -78.2 & 15.5 & 0.44 \\
$\mathrm{Q}_{1}(-78 \pm 2 \mathrm{ppm})$ & -78.4 & 4.3 & 0.0001 \\
$\mathrm{Q}_{2}(1 \mathrm{Al})(-82 \pm 2 \mathrm{ppm})$ & -81.2 & 4.3 & 0.0001 \\
$\mathrm{Q}_{2}(-85 \pm 2 \mathrm{ppm})$ & -84.2 & 4.3 & 0.0001 \\
$\mathrm{Q}_{\text {poly }}($ precipitated & -88.3 & 8.6 & 0.0001 \\
silicate $)$ & & & \\
\hline
\end{tabular}

increased $\mathrm{TiO}_{2}$ content was found almost identical to the position of $\mathrm{S} 1$, the GGBFS with normal $\mathrm{TiO}_{2}$ content. Due to the minimal change in the peak positions either the Ti occurs in tetrahedral coordination or the concentration of $\mathrm{TiO}_{2}$ in the GGBFS is too low to detect a clear shift. On the other hand, a content of nearly $2 \mathrm{wt} \% \mathrm{TiO}_{2}$ is relatively high for industrial practice already and lead to significantly altered reaction behavior of the GGBFS [4].

$\mathrm{Al}_{2} \mathrm{O}_{3}$ in the glass can function as a network modifier and as a network former [34]. The shift of a $\mathrm{SiO}_{4}$ group depend on the degree of $\mathrm{SiO}_{4}$ polymerization $\left(\mathrm{Q}_{\mathrm{n}}\right)$ and the number of $\mathrm{Si}$ or $\mathrm{Al}$ atoms in the second coordination sphere of the central silicon. In general, each substitution of a $\mathrm{Si}$ atom by an $\mathrm{Al}$ atom causes a down field shift of about 5 ppm [35]. In Table 5 it can be seen that an increase of the $\mathrm{Al}_{2} \mathrm{O}_{3}$ 
content (S1 and S3) resulted in a slight shift of the peak maxima to higher field in the ${ }^{29} \mathrm{Si}$ NMR spectra, which is attributed to the function of $\mathrm{Al}_{2} \mathrm{O}_{3}$ as a network former.

Figure 3 shows the ${ }^{29} \mathrm{Si}$ NMR spectra of the GGBFSs with varied basicity(C/S-ratio). A rising $\mathrm{C} / \mathrm{S}$-ratio means that the content of $\mathrm{CaO}$ increases with a simultaneous decrease of $\mathrm{SiO}_{2}$ which will result in a less condensed glass network. Conversely, the glass network is higher condensed at a low C/S-ratio, which can be seen in the ${ }^{29} \mathrm{Si}$ NMR spectrum by a clear upfield shift. With increasing polymerization of $\mathrm{Q}_{n}$ building units a characteristic upfield shift is observed in solid silicates from about $-65 \mathrm{ppm}$ for $\mathrm{Q}_{0}$ in monosilicates up to about $-110 \mathrm{ppm}$ for $\mathrm{Q}_{4}$ groups in fully polymerized silica. One condensation step $\left(\mathrm{Q}_{0} \rightarrow\right.$ $\left.\mathrm{Q}_{1} \rightarrow \mathrm{Q}_{2} \rightarrow \mathrm{Q}_{3} \rightarrow \mathrm{Q}_{4}\right)$ is correlated to a peak shift of approximately $10 \mathrm{ppm}$. [35] Starting from S1 which has a C/S-ratio of 1.22, the peak of S5 (C/S-ratio 0.86) is shifted upfield and the peak of S4 (C/S-ratio 1.42) is shifted downfield, as expected.

The quantitative determination of the reaction products of alkali-activated GGBFS was done after 28 days of hydration. In some cases the measurements showed overlapping signals, for which reason three binders were re-examined after 180 days of hydration.

The reaction products of alkali-activated slags can quantitatively be determined by a peak deconvolution. From the known peak parameters of the blast furnace slag ( $-74 \pm 2$ ppm respectively Table 5) and C-(A)$\mathrm{S}-\mathrm{H}$ phases $\left(\mathrm{Q}_{1}:-78 \pm 2 \mathrm{ppm}, \mathrm{Q}_{2}(1 \mathrm{Al}):-82 \pm\right.$ $2 \mathrm{ppm}, \mathrm{Q}_{2}$ : $-85 \pm 2 \mathrm{ppm}$ ) a theoretical curve was calculated and approximated to the measured data by only changing the amount of the single signals in such way that a minimum deviation was achieved. This gives information about the proportions of the individual signals for the different chemical environments of the silicon atom. First, the pure GGBFS were adjusted by setting a glass peak. Afterwards the 180 days old binder with $\mathrm{S} 1$ activated with $\mathrm{NaOH}$ was selected to define the peak parameter of the C-(A)-S-H phases $\mathrm{Q}_{1}, \mathrm{Q}_{2}(1 \mathrm{Al})$ and $\mathrm{Q}_{2}$. These parameters (Table 5) were considered for further evaluation as constant. It is assumed that the C-(A)-S-H phases of the same system will have the same peak position and shape. A similar approach was described in [36, 37].

The GGBFS activated with potassium silicates had an additional signal showed up as a broad shoulder around $-90 \mathrm{ppm}$. There are approaches which correlated these signals with aluminosilicate compounds $\left(\mathrm{Q}_{4}(3 \mathrm{Al})\right.$ and $\left.\mathrm{Q}_{4}(2 \mathrm{Al})\right)$, such as in alkaliactivated mixtures of blast furnace slag and metakaolin [38]. Another possible explanation could be that pure silicate gel is precipitated. If silicate is mixed with blast furnace slag, it can lead to a withdrawal of colloid or constitution water resulting in a condensation of colloidal silica oligomers due to the large surface of GGBFS particles that has to be wetted [39, 40]. Therefore silicate bridges between the slag particles might be formed, which condensated during solidification and formed solid gel structures [40]. Brough et al. [41] as well observed a signal which is substantially at $-90 \mathrm{ppm}$. They assigned this peak to cross-linked calcium or aluminum substituted silicate species, which they summarized as $\mathrm{Q}_{\text {poly }}$ for all polymerized silicate species in general. For this reason, a 180 day old binder S3 activated with K-WG-2 was used to identify the signal of the "precipitated silicate" $\left(\mathrm{Q}_{\text {poly }}\right)$. Figure 4 shows the deconvoluted ${ }^{29} \mathrm{Si}$ NMR spectra of the 28 and 180 days old binder of slag S1 activated with $\mathrm{NaOH}$ as exemplary results of the deconvolution.

From the deconvolution results, the degree of reaction (DR) of GGBFS, the average chain length (mean chain length-MCL) and the Si/Al-ratio of the C-(A)-S-H phases are calculated [35, 38, 42, 43]. The formulas are quoted elsewhere [38]. The calculation results are listed in Table 6.

By comparing the results of the 28 and 180 days old samples an increase in the degree of reaction can be observed in all three samples with increasing age, which is significantly higher in the binder with $\mathrm{S} 1$ than in the binder with S3. The Si/Al-ratio increases slightly with increasing age of the binder activated with $\mathrm{NaOH}$, while it remains constant for the sample activated with potassium silicate. The binder with $\mathrm{S} 3$ shows a slightly lower $\mathrm{Si} / \mathrm{Al}$-ratio in comparison to the binder with $\mathrm{S} 1$ (both activated with $\mathrm{NaOH}$ ). This means that more $\mathrm{Al}_{2} \mathrm{O}_{3}$ was incorporated into the chains of the C-(A)-S$\mathrm{H}$ phases. If silicate is used as activator, extra $\mathrm{Si}$ is introduced into the system, which on the one hand is available as "precipitated silicate" and on the other hand can be integrated into the C-(A)-S-H phases. Thus, the $\mathrm{Al}$ content is reduced in the $\mathrm{C}-(\mathrm{A})-\mathrm{S}-\mathrm{H}$ phases and their $\mathrm{Si} / \mathrm{Al}$-ratio increases. The longest chain lengths were calculated for $\mathrm{S} 3$ activated with $\mathrm{NaOH}$.

The NMR results of Table 6 can also be sorted by GGBFS characteristics. Slag with high C/S-ratio has a 
Fig. 4 Deconvoluted ${ }^{29} \mathrm{Si}$ MAS NMR spectra of alkali-activated slag paste of $\mathrm{S} 1$ and $\mathrm{NaOH}$ at the age of a 28 days and $\mathbf{b} 180$ days
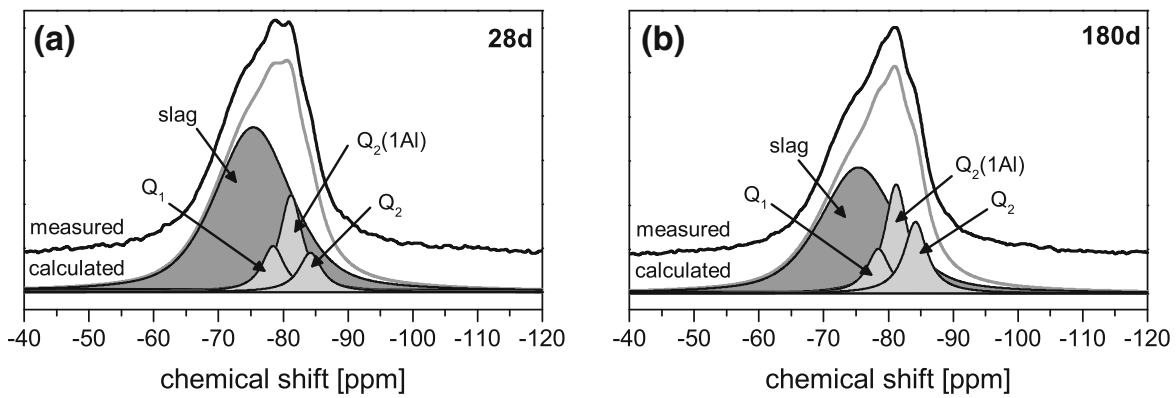

Table 6 Calculation results (mol\% Si) of deconvolution of the signal patterns of the spectra and calculated results of DR, MCL and $\mathrm{Si} / \mathrm{Al}$ of the activated binder

\begin{tabular}{|c|c|c|c|c|c|c|c|c|c|c|}
\hline \multirow[t]{3}{*}{ GGBFS } & \multirow[t]{3}{*}{ Activator } & \multirow{3}{*}{$\begin{array}{l}\text { Sample age } \\
\text { (days) }\end{array}$} & \multirow{3}{*}{$\begin{array}{l}\mathrm{Q}_{\text {poly }} \\
\text { (precipitated } \\
\text { silicate) } \\
-89 \mathrm{ppm} \\
(\mathrm{mol} \% \mathrm{Si})\end{array}$} & \multicolumn{3}{|c|}{ C-(A)-S-H phases } & \multirow{3}{*}{$\begin{array}{l}\text { Glass peak } \\
\text { of GGBFS } \\
\sim-75 \text { ppm } \\
\text { see Table } 5\end{array}$} & \multicolumn{2}{|c|}{ C-(A)-S-H phases } & \multirow{3}{*}{$\begin{array}{l}\text { DR } \\
\%\end{array}$} \\
\hline & & & & $\begin{array}{l}\mathrm{Q}_{2} \\
-85 \mathrm{ppm}\end{array}$ & $\begin{array}{l}\mathrm{Q}_{2}(1 \mathrm{Al}) \\
-82 \mathrm{ppm}\end{array}$ & $\begin{array}{l}\mathrm{Q}_{1} \\
-79 \mathrm{ppm}\end{array}$ & & MCL & $\mathrm{Si} / \mathrm{Al}$ & \\
\hline & & & & & & & & - & - & \\
\hline S1 & $\mathrm{NaOH}$ & 180 & 0.0 & 12.8 & 19.4 & 8.0 & 59.8 & 12.5 & 4.1 & 40.2 \\
\hline S3 & & & 0.0 & 8.7 & 17.7 & 4.2 & 69.4 & 18.6 & 3.5 & 30.6 \\
\hline S3 & K-WG-2 & & 13.4 & 12.4 & 11.3 & 9.0 & 53.9 & 8.6 & 5.8 & 32.7 \\
\hline S1 & $\mathrm{NaOH}$ & 28 & 0.0 & 6.3 & 15.5 & 7.4 & 70.8 & 10.0 & 3.8 & 29.2 \\
\hline $\mathrm{S} 2$ & & & 0.0 & 7.0 & 15.6 & 8.5 & 68.9 & 9.2 & 4.0 & 31.1 \\
\hline S3 & & & 0.0 & 5.0 & 17.7 & 3.8 & 73.5 & 18.5 & 3.0 & 26.5 \\
\hline S4 & & & 0.0 & 8.7 & 15.3 & 12.9 & 63.1 & 6.9 & 4.8 & 36.9 \\
\hline S5 & & & 0.0 & 7.1 & 7.7 & 3.4 & 81.8 & 13.0 & 4.7 & 18.2 \\
\hline S3 & K-WG-1 & & 4.5 & 9.7 & 11.2 & 3.8 & 70.8 & 16.1 & 4.4 & 24.7 \\
\hline S5 & & & 12.9 & 13.4 & 7.3 & 5.1 & 61.3 & 11.6 & 7.1 & 25.8 \\
\hline S3 & K-WG-2 & & 13.4 & 11.7 & 9.8 & 6.9 & 58.3 & 9.7 & 5.8 & 28.4 \\
\hline
\end{tabular}

depolymerized glass network, which can be split of quickly by an alkaline activator. This leads to a rapid formation of many small nuclei and a rapid growth of the reaction products, which are therefore of shorter length. The binders with S5, S1 and S4 clearly show an increase in the degree of reaction with increasing C/Sratio, with a simultaneous decrease of the chain length. This is reflected in significantly different strength developments (see Fig. 2). Comparing the samples with different $\mathrm{TiO}_{2}$ contents ( $\left.\mathrm{S} 1, \mathrm{~S} 2\right)$, only very small differences in chain length, degree of reaction and Si/Al-ratio can be observed. That reflects no clear influence of the $\mathrm{TiO}_{2}$ content on the reactivity of GGBFS within alkaline activated systems. Maybe the concentrations of $\mathrm{TiO}_{2}$ in the slags are too low, or the alkaline activation is not negatively influenced by $\mathrm{TiO}_{2}$. The increase of $\mathrm{Al}_{2} \mathrm{O}_{3}$ content caused a decrease in the degree of reaction, which could be attributed to the function of $\mathrm{Al}_{2} \mathrm{O}_{3}$ as a network former (slight upfield shift of the glass peak in Table 5). It has further be noticed that the average chain length of 18 was very high. This can partly be explained by the incorporation of $\mathrm{Al}$ into the $\mathrm{C}-(\mathrm{A})-\mathrm{S}-\mathrm{H}$ phases, which resulted in a lower $\mathrm{Si} / \mathrm{Al}$-ratio. It is noteworthy that the rise in $\mathrm{Al}_{2} \mathrm{O}_{3}$ content resulted in a significant increase in particular the early strength (Fig. 2).

Finally, it is possible to classify the results in Table 6 of $\mathrm{S} 3$ (GGBFS with high $\mathrm{Al}_{2} \mathrm{O}_{3}$ content) and S5 (GGBFS with low $\mathrm{C} / \mathrm{S}$ ratio) according to different activators. If the effect of the activators $\mathrm{NaOH}$, K-WG-1 and K-WG-2 is compared for the reaction of $\mathrm{S} 3$ it can be noticed, that the $\mathrm{SiO}_{2}$ content of the activator increases with increasing water glass module from 0 (for hydroxide) to 2 and therefore the $\mathrm{SiO}_{2}$ 
Table 7 Calculated results $\left(\% \mathrm{SiO}_{2}\right.$ molybdate active, rate constant $\left.\mathrm{k}\right)$ of the activated binder

\begin{tabular}{|c|c|c|c|c|c|c|c|}
\hline GGBFS & $\begin{array}{l}\mathrm{Al}_{2} \mathrm{O}_{3} \\
(\mathrm{wt} \%)\end{array}$ & $\mathrm{C} / \mathrm{S}(-)$ & Activator & $\begin{array}{l}\text { Age } \\
\text { (days) }\end{array}$ & $\begin{array}{l}\% \mathrm{SiO}_{2} \\
\text { molybdate active }\end{array}$ & $\begin{array}{l}\text { Rate constant } \\
\mathrm{k}\left(\min ^{-1}\right)\end{array}$ & $\begin{array}{l}\text { Time interval for } \\
\text { calculation of } k \text { (min) }\end{array}$ \\
\hline \multirow[t]{2}{*}{ S5 } & \multirow[t]{2}{*}{13.7} & \multirow[t]{2}{*}{0.86} & \multirow[t]{4}{*}{$\mathrm{NaOH}$} & \multirow[t]{4}{*}{28} & \multirow[t]{2}{*}{79.7} & 0.33 & $0.5-7$ \\
\hline & & & & & & 0.07 & $7-31$ \\
\hline S1 & 11.4 & 1.22 & & & 98.7 & 0.57 & $0.5-7$ \\
\hline S4 & 13.3 & 1.42 & & & 103.9 & 0.55 & $0.5-7$ \\
\hline \multirow[t]{2}{*}{ S5 } & \multirow[t]{2}{*}{13.7} & \multirow[t]{2}{*}{0.86} & \multirow[t]{4}{*}{ K-WG-1 } & \multirow[t]{4}{*}{28} & 80.6 & 0.28 & $0.5-7$ \\
\hline & & & & & & 0.12 & $7-25$ \\
\hline S1 & 11.4 & 1.22 & & & 97.0 & 0.50 & $0.5-7$ \\
\hline S4 & 13.3 & 1.42 & & & 108.0 & 0.45 & $0.5-7$ \\
\hline \multirow[t]{5}{*}{$\mathrm{S} 1$} & \multirow[t]{5}{*}{11.4} & \multirow[t]{5}{*}{1.22} & \multirow[t]{5}{*}{ K-WG-1 } & 1 & 96.1 & 0.64 & $0.5-7$ \\
\hline & & & & 7 & 99.1 & 0.47 & $0.5-7$ \\
\hline & & & & 28 & 97.0 & 0.50 & $0.5-7$ \\
\hline & & & & 180 & 106.7 & 0.58 & $0.5-3$ \\
\hline & & & & & & 0.27 & $3-10$ \\
\hline \multirow[t]{7}{*}{ S3 } & \multirow[t]{7}{*}{21.6} & \multirow[t]{7}{*}{1.22} & \multirow[t]{7}{*}{ K-WG-2 } & 1 & 84.8 & 0.45 & $0.5-7$ \\
\hline & & & & 7 & 86.3 & 0.40 & $0.5-7$ \\
\hline & & & & & & 0.20 & $7-12$ \\
\hline & & & & 28 & 86.4 & 0.37 & $0.5-7$ \\
\hline & & & & & & 0.10 & $7-19$ \\
\hline & & & & 180 & 108.6 & 0.40 & $0.5-7$ \\
\hline & & & & & & 0.04 & $7-29$ \\
\hline
\end{tabular}

content in the overall system. The $\mathrm{Si} / \mathrm{Al}$-ratio reflects this very well. With increasing $\mathrm{SiO}_{2}$ content in the overall system more $\mathrm{SiO}_{2}$ was incorporated into the $\mathrm{C}-(\mathrm{A})-\mathrm{S}-\mathrm{H}$ phases than $\mathrm{Al}_{2} \mathrm{O}_{3}$. This reduced the bridging effect of the $\mathrm{Al}_{2} \mathrm{O}_{3}$ and the average chain length was reduced. Furthermore, the proportion of "precipitated silicate" raised with increasing $\mathrm{SiO}_{2}$ content of the activator. S5 is less reactive due to its low C/S-ratio, but also for this slag could be confirmed, that the increasing $\mathrm{SiO}_{2}$ content of the activators led to a rise of the Si/Al-ratio and consequently to a decrease in the chain length.

\subsection{Molybdate method}

The degree of linkage of the $\mathrm{SiO}_{2}$ in the sample can be inferred from the reaction kinetic of the silicate to the yellow colored $\beta$-silico-molybdic acid complex. In the case of alumosilicates only the degree of condensation of the (remaining) silicates can be measured [24], because of the dissolution of the sample in acid in what the $\mathrm{Al}-\mathrm{O}-\mathrm{Si}$ bonds will be broken.
The pure slag samples reacted completely within 3 min to $\beta$-silico-molybdic acid. The calculated rate constants of $1.2-1.5 \mathrm{~min}^{-1}$ indicate a mixture of monomeric and dimeric silicate species.

The results of the measured binders include information of the slag glass and the formed reaction products. A clear separation and quantification is difficult. Therefore Table 7 lists the rate constants and in addition the time intervals, which were used for calculation. For some samples two rate constants could be calculated by two straight portions of the curve.

Figure $5 \mathrm{a}, \mathrm{b}$ shows the formation rates of $\beta$-silicomolybdic acid for alkali activated binders with different C/S-ratios of the slag activated with $\mathrm{NaOH}$ and K-WG-1. Comparing these results in the upper part of Table 7, it is found that the amount of molybdate active $\mathrm{SiO}_{2}$ decreases from about 100 to $80 \%$ with decreasing C/S-ratio for both activators $\mathrm{NaOH}$ and K-WG-1 for 28 day old samples. This means that a part of the silicate species in the binder is so long that it cannot be measured with the molybdate method, which explains the lower proportion of molybdate active $\mathrm{SiO}_{2}$. The rate constant 
Fig. 5 Formation rates of $\beta$-silico-molybdic acid for alkali activated binders with different $\mathrm{CaO} / \mathrm{SiO}_{2}$ ratios of the slag activated with a $\mathrm{NaOH}$ and $\mathbf{b} \mathrm{K}-\mathrm{WG}-1$ as well as binders with different $\mathrm{Al}_{2} \mathrm{O}_{3}$ contents of the slag activated with $\mathbf{c} \mathrm{K}$ WG-1 and $\mathbf{d}$ K-WG-2 at different age
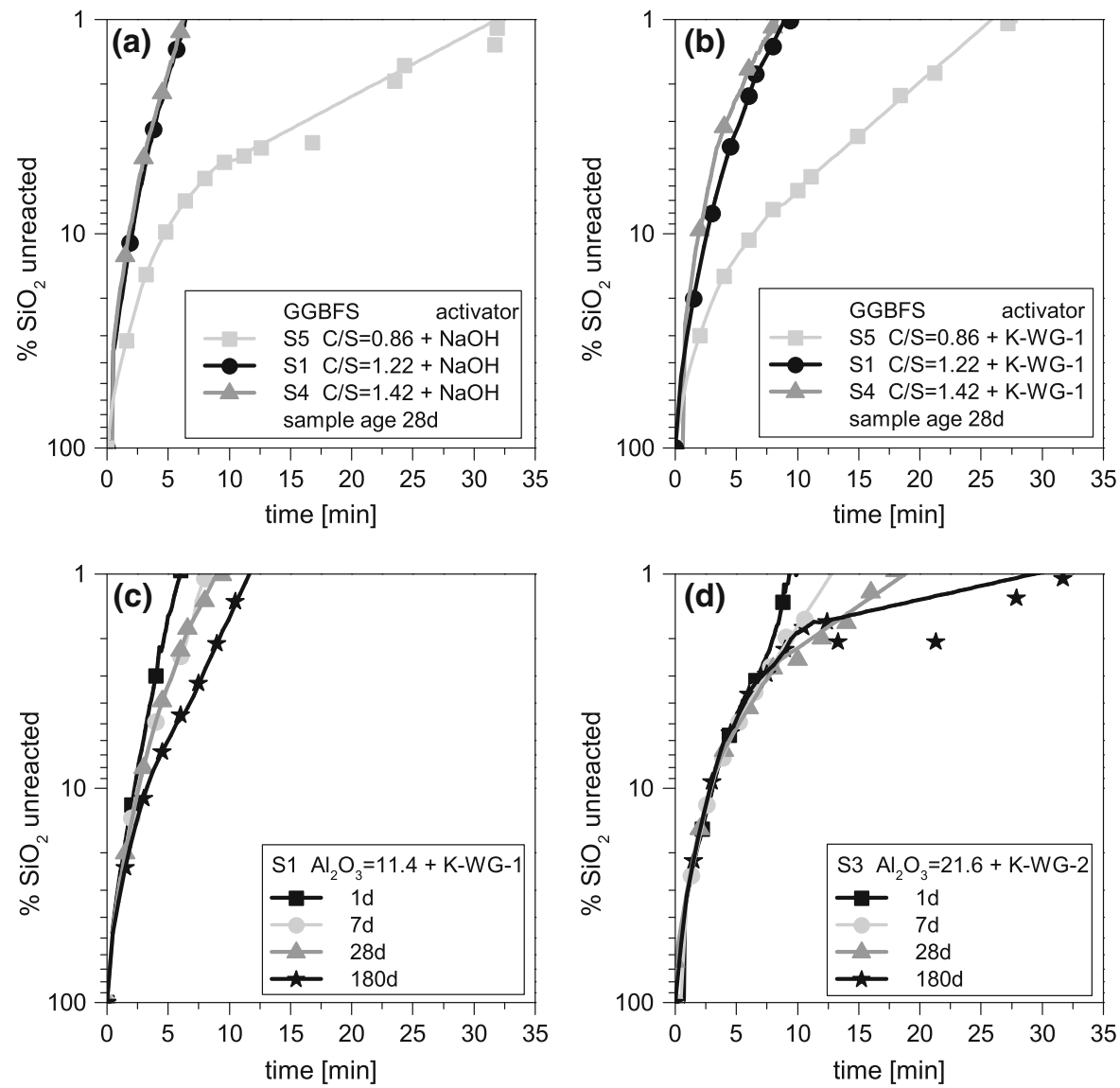

decreases as well, which indicates oligomer silicate species. The rate constants of 0.33 and 0.28 (S5 with $\mathrm{C} / \mathrm{S}=0.86$ ) as found for the 28 day old samples activated with $\mathrm{NaOH}$ and K-WG-1 respectively, indicate a $\mathrm{SiO}_{2}$ unit length of about 8-10, while the rate constants between 0.45 and 0.57 ( $\mathrm{S} 1$ and $\mathrm{S} 4$ with $\mathrm{C} / \mathrm{S}=1.22$ and 1.42 respectively) point out to a length of $6-8 \mathrm{SiO}_{2}$ units. The sample S5 $(\mathrm{C} / \mathrm{S}=0.86)$ activated with $\mathrm{NaOH}$ contains in addition a small amount of polysilicates (rate constant of 0.07) and in the binder with S5 activated with K-WG-1 some of the silicate species are longer than 10 $\mathrm{SiO}_{2}$ units (rate constant of 0.12).

Figure 5c, d show binder samples, which were measured after different sample age. With increasing sample age, the increase in conversion curves declines and more time is needed for the reaction of the $\mathrm{SiO}_{2}$ to the yellow $\beta$-silico-molybdic acid complex. This is also semi-quantitative illustrated by the decreasing rate constants (the bottom half of Table 7). With increasing sample age a transformation of the silicate species took place from smaller oligomers to longer chains with more $\mathrm{SiO}_{2}$ units. In the case of $\mathrm{S} 1$ and $\mathrm{K}-\mathrm{WG}-1$, the rate constants from 0.47 to 0.64 indicate chain lengths of about 6-8 $\mathrm{SiO}_{2}$ units for 1-28 day old samples. After 180 days some of the silicate species were about $8-10 \mathrm{SiO}_{2}$ units long (rate constant of 0.27). The binder which consists of $\mathrm{S} 3$ and K-WG-2 formed longer reaction products of $8-10 \mathrm{SiO}_{2}$ units (rate constants from 0.37 to 0.45 ). This was probably due to the increased $\mathrm{SiO}_{2}$ content of the activator. Already after 7 days a small amount of silicates is higher polymerized (about $10 \mathrm{SiO}_{2}$ units, rate constant of 0.20 ) than the other silicates. With further sample age the chain length grew to silicate species longer 10 $\mathrm{SiO}_{2}$ units (rate constant of 0.10 after 28 days) and polysilicates (rate constant of 0.04 after 180 days).

\section{Summary}

An increase in $\mathrm{TiO}_{2}$ content leads to a slight acceleration of the hydration in the case of K-WG-1. But a 
significant impact on the hydration observed by calorimetry was not visible. The influence of the $\mathrm{TiO}_{2}$ contents on the compressive strength was much more significant. An increase of $\mathrm{TiO}_{2}$ content causes higher strength especially by activation with $\mathrm{NaOH}$ which is at least partly due to the higher fineness of the slag with the highest $\mathrm{TiO}_{2}$ content. But nevertheless it can be assumed that with alkaline activation no major losses in the hydraulic reactivity of slags with high $\mathrm{TiO}_{2}$ content will be observed. The results in ${ }^{29} \mathrm{Si}$ NMR show only very small differences in the degree of reaction, chain length and $\mathrm{Si} / \mathrm{Al}$-ratio of the reaction products $\mathrm{C}-(\mathrm{A})-\mathrm{S}-\mathrm{H}$ phases.

Changing the $\mathrm{Al}_{2} \mathrm{O}_{3}$ content of the slag did not lead to a systematic change in the hydraulic reactivity. It strongly depends on the used activator. The same was observed by measuring the compressive strength. A rise in $\mathrm{Al}_{2} \mathrm{O}_{3}$ content enhances the strength when activated with $\mathrm{NaOH}$ but reduces it when activated with K-WG-1. The results of ${ }^{29} \mathrm{Si}$ NMR depict a decrease in the degree of reaction with increase of $\mathrm{Al}_{2} \mathrm{O}_{3}$ content in the slag glass. Simultaneously the chain length rises by incorporation of $\mathrm{Al}$ in the $\mathrm{C}$-(A)$\mathrm{S}-\mathrm{H}$ phases, which reveals in a lower $\mathrm{Si} / \mathrm{Al}$-ratio.

The impact of the $\mathrm{CaO} / \mathrm{SiO}_{2}$ ratio on the reactivity depends on the activator. A decrease in the C/S-ratio yields in case of K-WG-1 to a delay of hydration and in case of $\mathrm{NaOH}$ and K-WG-1 in a lower heat evolution. The C/S-ratio influences the early strengths after 1 day in the same way. A low C/S-ratio results in a low compressive strength and a high $\mathrm{C} / \mathrm{S}$-ratio implicate a high compressive strength. But regarding the binder with K-WG-1 this behavior is changing. The late strength of the slag with the lowest C/S-ratio exceeds the other binders. This is due to a densification of the structure by precipitated $\mathrm{SiO}_{2}$. Regarding the results of ${ }^{29} \mathrm{Si}$ NMR it could be measured that an increase of the $\mathrm{C} / \mathrm{S}$-ratio causes in less condensed slag glass and therefore show an enhancement in the degree of reaction, with a simultaneous decrease of chain length. This decrease in chain length could also be detected with the molybdate method for $\mathrm{NaOH}$ as well as for K-WG-1 as activator. Furthermore the calculated chain lengths of $7-13\left({ }^{29} \mathrm{Si} \mathrm{NMR}\right)$ for the binders with $\mathrm{NaOH}$ fit well with the calculated chain lengths of 6-10 measured by the molybdate method.

Acknowledgments The authors thank Dr. A. Ehrenberg (FEhS) and Dr. J. Krakehl (Woellner) for the supply of slag and waterglass, Dr. H. Hilbig (cbm, TU Munich) for the NMR measurements and A. Dobbertin for support in the lab. The investigations presented here, were funded by the $\mathrm{AiF}$ on behalf of the German Federal Ministry for Economics and Technology in the project "Alkali activated ground granulated blast-furnace slags for concrete application under aggressive conditions (IGF project 15800 BG)" and the German Federal Ministry of Education and Research in the project "Chemically Bonded Ceramics by Nanotechnological Improvements of Structure (03X0067G)".

Open Access This article is distributed under the terms of the Creative Commons Attribution License which permits any use, distribution, and reproduction in any medium, provided the original author(s) and the source are credited.

\section{References}

1. Forschungsgemeinschaft-Eisenhüttenschlacken (2000) Iron and steel slags-properties and utilisation-Reports from 1974-2000, Duisburg

2. Smolczyk HG (1978) Zum Einfluß der Chemie des Hüttensands auf die Festigkeiten von Hochofenzementen. ZKG Int 31(6):294-296

3. Schröder F (1961) Über die hydraulischen Eigenschaften von Hüttensanden und ihre Beurteilungsmethoden. Tonindustrie-Zeitung 85(2/3):39-44

4. Ehrenberg A (2006) Hüttensand-Ein leistungsfähiger Baustoff mit Tradition und Zukunft-Teil 2. Beton-Informationen (5):67-95

5. Tetmajer L (1886) Der Schlackenzement. Stahl und Eisen 6(7):473-483

6. DIN EN 197-1 (2011) Zement-Teil 1 Zusammensetzung, Anforderungen und Konformitätskriterien von Normalzement

7. DIN EN 15167-1 (2005) Hüttensand zur Verwendung in Beton, Mörtel und Einpressmörtel - Teil 1. Definitionen, Anforderungen und Konformitätskriterien

8. Deutsche Normen für einheitliche Lieferung und Prüfung von Eisenportland-Zement (1909)

9. Keil F (1963) Hochofenschlacke. Stahleisen-Bücher Band 7. Verlag Stahleisen mbH, Düsseldorf

10. Ehrenberg A, Wilhelm D, Kühn A et al (2008) Granulated blastfurnace slag-reaction potential and production of optimized cements, Part 2. Cem Int 6(3):82-92

11. Mußgnug G (1938) Die hydraulischen Eigenschaften der Hochofenschlacke. Mitteilungen aus den Forschungsanstalten des GHH-Konzerns 6(7):153-180

12. Dölbor F (1963) Einfluß der Abkühlungsbedingungen und der chemischen Zusammensetzung auf die hydraulischen Eigenschaften von Hämatitschlacken. Doctoral Thesis

13. Sakulich AR, Anderson E, Schauer CL et al (2010) Influence of Si: Al ratio on the microstructural and mechanical properties of a fine-limestone aggregate alkali-activated slag concrete. Mater Struct 43(7):1025-1035

14. Ben Haha M, Lothenbach B, Le Saout G et al (2012) Influence of slag chemistry on the hydration of alkali-activated blast-furnace slag-Part II: effect of $\mathrm{Al}_{2} \mathrm{O}_{3}$. Cem Concr Res 42(1):74-83 
15. Ben Haha M, Lothenbach B, Le Saout G et al (2011) Influence of slag chemistry on the hydration of alkali-activated blast-furnace slag-Part I. Eff $\mathrm{MgO}$ Cem Concr Res 41(9):955-963

16. Bernal SA, San Nicolas R, Myers RJ et al (2014) $\mathrm{MgO}$ content of slag controls phase evolution and structural changes induced by accelerated carbonation in alkali-activated binders. Cem Concr Res 57:33-43

17. Wolter A, Frischat GH, Olbrich E (2003) Investigation of granulated blast furnace slag (GBFS) reactivity by SNMS. In: $11^{\text {th }}$ International Congress on the Chemistry of Cement

18. Wang PZ, Rudert V, Lang E et al (2002) Influence of the $\mathrm{TiO}_{2}$ content on the reactivity of granulated blastfurnace slags. Cem Int 1(1):120-128

19. Stephan D, Tänzer R, Braun T et al (2010) Alkali activation-an alternative to binders that contain clinker; Part 1/2. Cem Int 8(1/2):72-85/74-81

20. Drissen P (1994) Glasgehaltsbestimmung von Hüttensand. ZKG Int 47(11):658-661

21. Stade H (1978) Zur Bildungskinetik der B-Dodekamolybdatokieselsäure. I. Die Umsetzung von monokieselsäure mit Molybdänsäure. Z Anorg Allg Chem 441(1):29-38

22. Stade H (1978) Zur Bildungskinetik der $\beta$-Dodekamolybdatokieselsäure. II. Die Umsetzung von kondensierten Kieselsäuren mit Molybdänsäure. Z Anorg Allg Chem 446(1):5-16

23. Thilo E, Wieker W, Stade H (1965) Chemische Untersuchungen von Silicaten, XXXI. Über Beziehungen zwischen dem Polymerisationsgrad silicatischer Anionen und ihrem Reaktionsvermögen mit Molybdänsäure. Z Anorg Allg Chem 340(5-6):261-276

24. Hoebbel D, Garzó G, Ujszászi K et al (1982) Herstellung und Anionenkonstitution von kristallinen Tetramethylammonium-alumosilicaten und -alumosilicatlösungen. Z Anorg Allg Chem 484(1):7-21

25. Hoebbel D, Ebert R, Wieker W et al (1988) Über die Anwendung der Farbstoffadsorptionsmethode zur Charakterisierung von Natriumsilicat-(Wasserglas-) lösungen. Z Anorg Allg Chem 558(1):171-188

26. Hoebbel D, Wieker W (1971) Die Konstitution des Tetramethylammoniumsilicats der Zusammensetzung 1,0 N(CH3) 4OH 1,0 SiO2 · 8,0-8,3 H2O. Z Anorg Allg Chem 384(1): $43-52$

27. O'Connor TL (1961) The reaction rates of polysilicic acids with molybdic acid. J Phys Chem 65(1):1-5

28. Hübert C. et al. (received 2013) Collection of rate constants $\mathrm{k}$ of different silicate species, B TU Cottbus-Senftenberg
29. Wang PZ, Trettin R, Rudert V et al (2004) Influence of $\mathrm{Al}_{2} \mathrm{O}_{3}$ content on hydraulic reactivity of granulated blastfurnace slag, and the interaction between $\mathrm{Al}_{2} \mathrm{O}_{3}$ and $\mathrm{CaO}$. Adv Cem Res 16(1):1-7

30. Zachariasen WH (1932) The atomic arrangement in glass. J Am Chem Soc 54(10):3841-3851

31. Zachariasen WH (1933) Die Struktur der Gläser. Glastechnische Berichte 11

32. Labouriau A, Higley TJ, Earl WL (1998) Chemical shift prediction in the ${ }^{29} \mathrm{Si}$ MAS NMR of titanosilicates. J Phys Chem B 102(16):2897-2904

33. Balmer ML, Bunker BC, Wang LQ et al (1997) Solid-state ${ }^{29}$ Si MAS NMR study of titanosilicates. J Phys Chem B 101(45):9170-9179

34. Shi C, Krivenko PV, Roy D (2006) Alkali-activated cements and concrete. Taylor and Francis, New York

35. Engelhardt G, Michel D (1987) High Resolution solid state NMR of silicates and zeolithes. Wiley, Chichester

36. Schilling PJ, Butler LG, Roy A et al (1994) ${ }^{29} \mathrm{Si}$ and ${ }^{27} \mathrm{Al}$ MAS-NMR of NaOH-activated blast-furnace slag. J Am Ceram Soc 77(9):2363-2368

37. Schneider J, Cincotto MA, Panepucci H (2001) ${ }^{29} \mathrm{Si}$ and ${ }^{27} \mathrm{Al}$ high-resolution NMR characterization of calcium silicate hydrate phases in activated blast-furnace slag pastes. Cem Concr Res 31(7):993-1001

38. Buchwald A, Hilbig H, Kaps C (2007) Alkali-activated metakaolin-slag blends-performance and structure in dependence of their composition. J Mater Sci 42(9):3024-3032

39. Goberis S, Antonovich V (2004) Influence of sodium silicate amount on the setting time and EXO temperature of a complex binder consisting of high-aluminate cement, liquid glass and metallurgical slag. Cem Concr Res 34(10):1939-1941

40. Zellmann HD, Ch K (2006) Chemically modified waterglass binders for acid-resistant mortars. J Am Ceram Soc 89(4):1369-1372

41. Brough AR, Holloway M, Sykes J et al (2000) Sodium silicate-based alkali-activated slag mortars Part II. The retarding effect of additions of sodium chloride or malic acid. Cem Concr Res 30(9):1375-1379

42. Hilbig H, Buchwald A (2006) The effect of activator concentration on reaction degree and structure formation of alkali-activated ground granulated blast furnace slag. J Mater Sci 41(19):6488-6491

43. Andersen MD, Jakobsen HJ, Skibsted J (2004) Characterization of white Portland cement hydration and the C-S-H structure in the presence of sodium aluminate by ${ }^{27} \mathrm{Al}$ and ${ }^{29}$ Si MAS NMR spectroscopy. Cem Concr Res 34:857-868 